\title{
Slavko Osterc's Compositional Journey and his Assimilation of New Techniques
}

\author{
Niall O'Loughlin \\ Univerza v Loughboroughu \\ Loughborough University
}

\section{Introduction}

The composing career of the leading Slovene composer Slavko Osterc (18951941) spanned the twenty years from 1921 to 1941. During this time his style developed in stages from a late Romantic idiom through various modifications to a well developed approach that incorporated numerous new musical techniques, many of which were passed on to his numerous Slovene composition pupils.

\section{Early Years 1921-1925}

There are some forty compositions of his dating from before his departure for Prague. ${ }^{I}$ Andrej Rijavec is dismissive of the simplistic view that they were somewhat immature, with a more or less romantic expression. ${ }^{2} \mathrm{He}$ notes in two selected chamber music works an interesting harmonic language which extends to the use of parallel chords, the loosening of the traditional progression of chords and the increasing 'indefinability' of chords by the supersaturation of seconds. The lucidity of form is attributed to his use of 'horizontal thought, whether a simple figure, a small motif, or a theme, even with melodic qualities." One substantial orchestral work from

$1 \quad$ Andrej Rijavec, "Komorno kompozicijsko snovanje Slavka Osterca pred njegovim odhodom v Prago," Muzikološki zbornik 5 (1969): 92-10o.

2 Ibid., 100.

3 Ibid., 100 . 
this period, the Symphony in C major of 1922, subtitled Ideali ('Ideals'), is traditional in its form and techniques. ${ }^{4}$ The last work of any substance from this time is his first opera Krst pri Savici ('Baptism at the Savica') with a story that has roots in Slovene history and mythology. It is through composed, but it is possible to identify traditional set-pieces such as arias, duets and ensembles. This technique of having the best of both worlds is something that he also used in his later opera, Krog s kredo.

\section{Prague Years 1925-27}

The years in Prague were used by Osterc to extend his style and study new techniques. He was able to expand his horizons considerably and learn to use new techniques to embrace those of his teachers, establishing a very good relationship with them, but taking from each of them only what he wanted. He gained a good grounding in new techniques from Karel Boleslav Jirák, but also developed an adventurous side from Alois Hába. Although there is no evidence that Osterc had any dealings with Alexander Zemlinsky who was living in Prague at the time, it is quite possible that he was able to encounter some of his work while he was studying in that city. The fact that both Osterc and Zemlinsky used the play Der Kreidekreis by Klabund as librettos for operas in the next few years may not be the coincidence that it initially seems. At the same time, there is also another side to his musical experience: that his fondness for using the folk music of his native land could be integrated into his modernist tendencies.

\section{Experimental Ljubljana 1927-30}

After returning from his studies in Prague to Ljubljana, Osterc became very active in three main ways. The first of course was the composition of his new music, which he hoped would be widely performed. Secondly, he worked extensively with the International Society for Contemporary $\mathrm{Mu}$ -

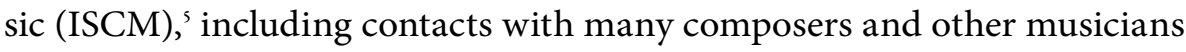
in the different republics of what was then Yugoslavia and further afield in numerous countries of Europe. The third important activity was his teaching of a significant number of composition pupils, whom he was able to en-

4 See the study Zoran Krstulović, "Kompozijski stavek Simfonije v C-duru ('Ideali') Slavka Osterca," Muzikološki zbornik 31 (1995): 53-62.

5 Normally referred to in continental Europe by its French name, Société internationale de la musique contemporaine (SIMC). 
courage technically and stylistically. Thus his influence operated on a number of different levels.

One of his pupils, the distinguished musicologist, Dragotin Cvetko (1911-1993), held Osterc in very high regard, pointing to the great significance of his compositions which dated from the last years of the 1920 in comparison with those of his contemporary Marij Kogoj (1892-1956):

"During the last years of the third decade of the 2oth century, it was Osterc who changed Slovene music, rather than Kogoj. Drawing intensively away from tradition in his ideas, he revolutionized the music of his time, though within the Slovene space and scale, not the European one. This is demonstrated by his works written during the years 1927-1930, which are different from those of his contemporaries and even from those of Kogoj, whose modernist inclination lay elsewhere. Even the first works written by the former [i.e. Osterc] foretold an even more radical grasp of the new style when compared to those by Kogoj.'

An examination of some of the music of these years is the key to the full understanding of the meaning of Cvetko's remarks. Osterc's main achievements in 1927-30 were in the fields of chamber music and opera. Much of the chamber music is small-scale in conception, with works divided into a number of separate short movements, often written for wind instruments. Štiri karikature ('Four Caricatures') for piccolo, clarinet and bassoon uses the widely spaced registers of the chosen instruments for clarity of texture, particularly in contrapuntal passages and in the sharply etched rhythms. There is an affinity with some music of Stravinsky in the clear colours of the Preludio, while the Fughetta finale is one of Osterc's distinctive character pieces of this period, with its playful contrapuntal character. Overall there is a feeling of humour and parody, especially in the Valse movement, with its sense of pastiche, precise rhythms and the use of widely differing wind instruments to mark out the clear-cut melodic lines. One finds the use of traditional dance forms from the baroque in his Silhuete ('Silhouettes') for string quartet of 1928. The longest of these five pieces is barely two minutes in duration while the shortest lasts a mere 30 seconds. The epigrammatic forms embrace a range of harmonic tension and discord that is rare in Slovene music of the period. Of the works using miniature forms, the delight-

6 Dragotin Cvetko, Fragment glasbene moderne iz pisem Slavku Ostercu - A Fragment of Musical Modernism from Letters to Slavko Osterc (Ljubljana: Slovenska akademija znanosti in umetnosti, 1988), 12 
fully entertaining Sonatina for two clarinets of 1929, with its contrapuntal textural variety of register differentiation, hides a range of discordant juxtapositions that is amazingly forward-looking. Also using short movements, but suggesting the possibility of longer paragraphs is the Suite of 1928, scored for a distinctive group of eight instruments, four woodwind, three brass and timpani. The first two movements have a more romantic feel, but the Tempo di Valse, the stern march-like Grave and the Vivo fughetta finale return to the lighter humour of the other pieces. Two more extended instrumental works also come from this time: the Koncert $z a$ violino in 7 instrumentov ('Concerto for violin and seven instruments') of 1927-28 and the Suite for orchestra of 1929, both with suggestions of Hindemith and Honegger. The Violin Concerto is cast in a single movement and scored for two woodwind, two brass, timpani and two strings in addition to the solo instrument. The way that Osterc planned the concerto's structure gives a clue to the single-movement forms that were soon to follow, while the orchestral Suite shows how the terse chamber-music miniatures could be extended. As a postscript to his time in Prague we note that the studies with Alois Hába resulted in only a small number of works that used his teacher's quarter-tone system, ones that had little bearing on Osterc's later development or on his influence on others.?

\section{New Operas 1928-29}

This period was one in which Osterc was also active as a vocal composer. There are a number of choruses which are less indicative of his more adventurous ideas, but ones in which the composer was able to keep a contact with his audiences and with Slovene traditional choral singing. More important for the development of newer techniques are solo songs and operas. The most impressive solo vocal work must be Štiri Gradnikove pesmi ('Four Songs to words of Alojz Gradnik') for alto and string quartet of 1929. Here there is none of the light and almost sarcastic sound of the wind instruments, but the brooding sounds of intense romanticism, the other side of Osterc's style. This movement between the romantic and the neo-classical is

7 The most important works are: Tri skladbe za četrttonski klavir, ca 1927, Štiri Heinejeve pesmi za višji glas in godalni kvartet $v$ četrttonskem sestavu, 1931 and Cvetoči bezeg, cantata 1936. A discussion of the importance and the extent of the influence of Hába on Osterc is discussed by Leon Stefanija in "Osterc in Hába," Muzikološki zbornik 31 (1995): 33-41. See also the paper by Jernej Weiss, "Alois Hába and Slovene students of composition at the State Conservatory in Prague," included in this volume. 
very much a part of his compositional activity of this period, ${ }^{8}$ which included the creation of no less than five operas. Admittedly four were only brief works, miniature dramas cast in a single act: his short operas Iz komične opere ('From the Opéra comique') of 1927 and the parody Saloma ('Salome') of 1929-30 caused great interest,' as did his Medea and Dandin v vicah ('Dandin in Purgatory'), both of 1930. Dandin v vicah is described as 'operna groteska', while Saloma is called 'minutna opera-parodija'. The latter in fact lasts a mere 11 minutes. ${ }^{10}$ It uses many of the features of the instrumental music to dramatic effect. Particularly notable is the wry and sardonic tone of the instrumental writing which supports the parodistic character of the story. Unlike in the traditional story of Salome, Herod is bored with Salome's dancing and calls for her to stop. Strauss's famous Dance of the Seven Veils is replaced, almost in cabaret fashion, by a rather tired waltz.

Moving on to consider the major opera of this period, Krog s kredo ('The Chalk Circle'), composed in the years 1928-29, one can imagine that Osterc was taking a somewhat cynical view of the subject and using all his musical resources to reinforce this idea in a full-length opera of imposing character. It showed a remarkable assurance in handling the operatic medium, but, like the instrumental works of the same period, also gave a clear indication of the techniques of some of the works to follow in the next decade.

The Chalk Circle play ${ }^{11}$ was originally Chinese, a story of rampant corruption, involving a magic method of deciding the truth between two disputants, something akin to the Judgement of Solomon as related in the Bible. ${ }^{12}$ In the early 1920s, the German poet and dramatist Klabund (the nom de plume of Alfred Henschke) rewrote a French translation of the play as

8 This dichotomy was explored in some detail by Ivan Klemenčič, "Slavko Osterc Composing Between Neoclassicism and Expressionism,” in: Primož Kuret, ed., Glasba med obema vojnama in Slavko Osterc (Ljubljana: Festival Ljubljana, 1995), 49-63 [Full English text with Slovene summary] and "Slavko Osterc med neoklasicizmom in ekspresionizmom," Muzikološki zbornik 31 (1995): 11-23 [in Slovene with English summary].

Jože Sivec, Dvesto let slovenske opere - Two Hundred Years of the Slovene Opera (1780-1980) (Ljubljana: Opera in Balet, 1981), 37-38, 91; Peter Andraschke, "Minutna opera 'Saloma' Slavka Osterca - Die Minutenoper 'Salome' von Slavko Osterc," in: Primož Kuret, ed., Slovenska glasba v preteklosti in sedanjosti - Slowenische Musik in vergangenheit und Gegenwart (Ljubljana: Kres, 1992), 204-15.

10 This length is an estimate derived from playing the score. Andraschke, op.cit. also gives this length, but the DSS catalogue surprisingly gives the duration as 20 minutes.

11 Hui-lan-chi or History of the Circle of Chalk, translated by Stanislas Julien as Le Cercle de Craie (London: John Murray, 1832). 
Der Kreidekreis with new characters and additional dramatic features, and published it in Berlin in $1925 .{ }^{13}$ Klabund's play soon became very popular all over Central Europe, with two operatic settings appearing in quick succession, the first by Osterc in a Slovene translation and the second by Alexander Zemlinsky completed in 1931 (Der Kreidekreis). ${ }^{14}$ Brecht later modified the story for his play The Caucasian Chalk Circle."

Osterc's opera presents a wide-ranging synthesis of his then current stylistic traits. Some notable features can be listed:

1. It is through composed, superficially abandoning the traditional separation of individual 'numbers'.

2. There are passages, however, in which traditional set-pieces such as arias, recitatives and choruses can be recognised, a feature that gives Osterc a foothold in the past. He composed transitions from one section to the next which maintained dramatic continuity, but which allowed him to set his words effectively.

3. The words of the strophic parts of the libretto are set almost as arias with uncomplicated melodies and flexible rhythms.

4. The prose parts of the text are set to flexible recitative-like vocal lines.

5. Orchestral counterpoints support and blend with the freely sung vocal parts without detracting from their interest and without disguising the words.

6. Recurrent musical motifs appear, some associated with the evil characters, as well as some related to the chalk circle itself, an effective dramatic device that was well known in many previous operas. There is no comprehensive system of Leitmotifs of a Wagnerian type.

7. The harmonies that Osterc used often contradict the possible tonal-harmonic implications of many of the vocal lines. There is a

13 Klabund [Alfred Henschke]: Der Kreidekreis (Berlin: J.M. Spaeth, 1925); Klabund: The Circle of Chalk, translated by James Laver (London: William Heinemann, 1929).

14 See Alfred Clayton, "Zemlinsky, Alexander," The New Grove Dictionary of Opera (London: Macmillan, 1992), vol.4, 1225-26 and "Kreidekreis, Der," Ibid., vol.2, 1043.

15 This was published as Der kaukasische Kreidekreis (Berlin: Suhrkamp Verlag, 1955) and in its English version by James and Tanya Stern with W. H. Auden as The Caucasian Chalk Circle (London: Methuen, 1960; revised version, London: Eyre Methuen, 1976). The latter replaced Eric Bentley's English version used in the first American production. 
feeling in the sound that Osterc wanted to write a romantic opera and produced the appropriate melodic lines, but at the same time concealed this impression by using harmonies that made the opera a much more 'modern' work.

8. The kaleidoscopic orchestration is allowed to transform itself from one section to the next with seamless transitions of the type which are found later in the Mouvement symphonique of 1936.

9. There are numerous unorthodox instrumental juxtapositions.

10. The scoring of the work makes full use of wind instruments in a most imaginative and unusual way, both in the contrapuntal webs that are spun around the vocal lines and in the bold homophonic instrumental interludes, which reveal harsh added-note harmonies.

The Chalk Circle was never performed in the composer's lifetime and the score was very nearly destroyed in a bombing raid. After the composer's death in 1941, the manuscript disappeared and for many years the score was considered lost. ${ }^{16}$ It re-emerged in the early 1990 s in time for performing material to be prepared at last for a production. The set of orchestral parts is preserved in the archives of Slovene National Opera in the Ljubljana Opera House, ${ }^{17}$ while the score is kept in the National and University Library in Ljubljana. Eventually it was first performed in 1995, the centenary of the composer's birth and some 60 years after his death, in Maribor, not far from the composer's birthplace in Veržej..$^{18}$ Its stature and importance have now been revealed.

\section{New Forms 1930-41}

It can now be seen that the groundwork of Osterc's modernism was fully established by 1930. We do not find him using fully atonal or 12-note tech-

16 In 1969, it was listed as "lost" by Danilo Pokorn, "Bibliografski pregled kompozicij Slavka Osterca," Muzikološki zbornik 6 (1969): 76. Apparently after the composer's death the score was passed by the composer's widow to Demetrij Žebrè and later to Uroš Lajovic before being used for producing the material for the Maribor production of 1995.

17 My thanks to Andrej Rijavec for help in tracing the orchestral parts in the Ljubljana Opera House archives in April 1994 and for recovering a copy of the full score for study purposes.

18 By the Slovene National Opera conducted by Simon Robinson in Maribor Opera House on 7 April 1995. The composer was born in Veržej in the Ljutomer region of Slovenia on 17 June, 1895. For more details of the opera see Niall O'Loughlin, "The Chalk Circle Operas of Osterc and Zemlinsky: a comparative Analysis," in: Primož Kuret, ed., Glasba med obema vojnama in Slavko Osterc - Musik zwischen beiden Weltkriegen und Slavko Osterc (Ljubljana: Festival Ljubljana, 1996), 64-76. 
niques ${ }^{19}$ nor do we find that his melodic, harmonic or contrapuntal techniques were as advanced as those of Schönberg, Berg or Webern. What we do discover that is new is a far-reaching development of formal construction, which can be seen in many of his works of the period. Even the light-hearted chamber works for wind instruments, the Kvintet za pihala ('Wind Quintet') and the Trio for flute, clarinet and bassoon, which are divided into a number of separate movements, show a fascinating involvement in methods of manipulating form by combining or juxtaposing tempos. The String Quartet No.2 ${ }^{20}$ and the Nonet, both cast in two movements, display to a remarkable extent a brilliant juggling of different tempos as a means of creating dramatic contrasts and tensions. Two of the major Sonatas for solo instrument and piano from this period, those for saxophone and for cello, are good examples of how Osterc created transitions between the sections in a seamless way. The former does this over two multi-tempo movements, while the latter, nominally in five separate movements, is played attacca, without a break and with expertly composed transitions and links between the movements. In orchestral works such as the Passacaglia in koral of 1934, the Mouvement symphonique of 1936 and the symphonic poem Mati of 1940 brief neoclassical miniatures are gone and in their place are developmental, monolithic structures that have their roots in the Koncert za violino in 7 instrumentov and the opera Krog s kredo. This breaking down of the traditional structures is an important aspect of Osterc's legacy to Slovene music.

\section{SIMC/ISCM}

Osterc's involvement with the ISCM (SIMC) was in the first place concerned with getting his music performed abroad among sympathetic audiences. This worked well for him with the performances of Štiri Gradnikove pesmi in Florence in 1932, the Concerto for piano and wind in 1935 in Prague, the Mouvement symphonique in London in 1938 and the Passacaglia in koral in Warsaw in 1939. Inevitably he was additionally drawn into correspondence, almost exclusively from 1930, with numerous musicians many of whose let-

19 Andrej Rijavec, "K vprašanju tonalnosti in verticale v skladbah Slavka Osterca," Muzikološki zbornik 6 (1970): 53

20 A full discussion of the extent of Osterc's 'avant-gardism' in this work is discussed by Marija Bergamo in “Osterčeva 'avantgardnost' v luči Drugega godalnega kvarteta (1934),” Muzikološki zbornik 31 (1995): 63-69. 
ters received by Osterc have been preserved. ${ }^{21}$ These give a fascinating picture of Osterc's activities, not only in promoting his own music, but also in the way that he encouraged the adoption of modernism in one form or another in new music. The list of composers with whom he corresponded was extensive. From outside Yugoslavia there were Luigi Dallapiccola, Karl Amadeus Hartmann, Arthur Honegger, Alois Hába, and Karel Boleslav Jirák. Within Yugoslavia but outside Slovenia, Osterc received letters from the composers Krešimir Baranović, Petar Bingulac, Dragutin Čolić, Jakov Gotovac, Fran Lhotka, Ljubica Marić, Miloje Milojević, ${ }^{22}$ Krsto Odak, Boris Papandopulo, Milan Ristić, Josip Slavenski, ${ }^{23}$ and Vojislav Vučković. Within Slovenia itself he corresponded with Marjan Kozina, Gojmir Krek, Bogo Leskovic, Marjan Lipovšek, Karol Pahor, Risto Savin, Pavel Šivic, Lucijan Marija Škerjanc, Franc Šturm, Danilo Švara and Demetrij Žebre. There are many more performing musicians, conductors especially, and some musicologists with whom he had significant contact. In all these letters it is clear that Osterc was fully conversant with new developments all over Europe and was very keen to encourage them wherever he could, but especially in his native Slovenia. The dedicatees of his works also give an indication of his contacts; the important ones are Prokofiev for the ballet Illusions (1937-41), Hába for the Concerto for piano and wind instruments of 1933, Hermann Scherchen for Plesi ('Dances') for orchestra of 1935, Karel Boleslav Jirák for Mouvement symphonique of 1936 and Arthur Honegger for the Nonet of 1937.

\section{Conclusion}

Finally, while Osterc did encounter opposition to his music from some quarters, he did not become estranged from the Slovene musical centre ground. He made many musical friends in Slovenia, in the rest of what was then Yugoslavia, as well as abroad to help his cause and was able to influence a number of his pupils to adopt an adventurous line of composition.

21 See the definitive collection of the most important letters in Dragotin Cvetko: Fragment glasbene moderne iz pisem Slavku Ostercu - A Fragment of Musical Modernism from Letters to Slavko Osterc (Ljubljana: Slovenska akademija znanosti in umetnosti, 1988).

22 The correspondence is fully documented by Dragotin Cvetko, "Kontakti Slavka Osterca z Milojem Milojevićem," Muzikološki zbornik 22 (1986): 39-52 and "Kontakti Slavka Osterca z Milojem Milojevićem," in Miloje Milojević kompozitor i muzikolog (Belgrade: Udruženje kompozitora Srbije, 1986), 173-203.

23 See Dragotin Cvetko's article "Veze Josipa Slavenskog sa Slavkom Ostercom," Arti Musices 3 (1972): 63-76. 
More recently, however, the perspective on his work has changed: Osterc's music today is not considered advanced according to Western European criteria, even if much of his music is still relatively little known. His music explored new formal workings and a harmonic idiom that verged on atonality and twelve-note working rather than strict serial technique. It is now understood and appreciated on its own terms, that is, without too much reference to the ideas of modernism. In all ways, however, Slovene music developed enormously under his influence.

\section{Bibliography}

Anon.. Hui-lan-chi or History of the Circle of Chalk. Translated into French by Stanislas Julien as Le Cercle de Craie. London: John Murray, 1832.

The Old Testament of the Bible, I Kings, 3, verses 16-28.

Andraschke, Peter. "Minutna opera 'Saloma' Slavka Osterca - Die Minutenoper 'Salome' von Slavko Osterc.” Kuret, Primož, ed.. Slovenska glasba $v$ preteklosti in sedanjosti - Slowenische Musik in vergangenheit und Gegenwart. Ljubljana: Kres, 1992, 204-15.

Bergamo, Marija. “Osterčeva 'avantgardnost' v luči Drugega godalnega kvarteta (1934).” Muzikološki zbornik 31 (1995): 63-69.

Brecht, Bertolt. Der kaukasische Kreidekreis. Berlin: Suhrkamp Verlag, 1955.

Brecht, Bertolt. (translated James and Tanya Stern with W.H. Auden). The Caucasian Chalk Circle. London: Methuen, 1960; revised, London: Eyre Methuen, 1976.

Clayton, Alfred. "Zemlinsky, Alexander.” The New Grove Dictionary of Opera. London: Macmillan, 1992, vol. 4, 1225-26.

Clayton, Alfred. "Kreidekreis, Der." The New Grove Dictionary of Opera. London: Macmillan, 1992, vol. 2, 1043.

Cvetko, Dragotin. Fragment glasbene moderne iz pisem Slavku Ostercu - A Fragment of Musical Modernism from Letters to Slavko Osterc. Ljubljana: Slovenska akademija znanosti in umetnosti, 1988.

Cvetko, Dragotin. “Kontakti Slavka Osterca z Milojem Milojevićem.” Muzikološki zbornik 22 (1986): 39-52.

Cvetko, Dragotin. “Kontakti Slavka Osterca z Milojem Milojevićem.” In Miloje Milojević kompozitor i muzikolog. Belgrade: Udruženje kompozitora Srbije, 1986, 173-203.

Cvetko, Dragotin. "Veze Josipa Slavenskog sa Slavkom Ostercom.” Arti Musices 3 (1972): 63-76. 
Klabund [Alfred Henschke]. Der Kreidekreis. Berlin: J. M. Spaeth, 1925.

Klabund (translated James Laver). The Circle of Chalk. London: William Heinemann, 1929.

Klemenčič, Ivan. "Slavko Osterc Composing Between Neoclassicism and Expressionism.” In: Kuret, Primož, ed.. Glasba med obema vojnama in Slavko Osterc. Ljubljana: Festival Ljubljana, 1995, 49-63 [Full English text with Slovene summary].

Klemenčič, Ivan. "Slavko Osterc med neoklasicizmom in ekspresionizmom." Muzikološki zbornik 31 (1995): 11-23 [in Slovene with English summary].

Krstulović, Zoran. “Kompozijski stavek Simfonije v C-duru ('Ideali') Slavka Osterca.” Muzikološki zbornik 31 (1995): 53-62.

O’Loughlin, Niall. “The Chalk Circle Operas of Osterc and Zemlinsky: a comparative Analysis." In: Kuret, Primož, ed.. Glasba med obema vojnama in Slavko Osterc - Musik zwischen beiden Weltkriegen und Slavko Osterc. Ljubljana: Festival Ljubljana, 1996, 64-76.

Pokorn, Danilo. "Bibliografski pregled kompozicij Slavka Osterca." Muzikološki zbornik 6 (1969): 76.

Rijavec, Andrej. "Komorno kompozicijsko snovanje Slavka Osterca pred njegovim odhodom v Prago.” Muzikološki zbornik 5 (1969): 92-10o.

Rijavec, Andrej. “K vprašanju tonalnosti in verticale v skladbah Slavka Osterca.” Muzikološki zbornik 6 (1970): 53.

Sivec, Jože. Dvesto let slovenske opere - Two Hundred Years of the Slovene Opera (1780-1980). Ljubljana: Opera in Balet, 1981, 37-38, 91.

Stefanija, Leon. “Osterc in Hába.” Muzikološki zbornik 31 (1995): 33-41. 